\title{
THE SOCIOECONOMIC VULNERABILITY OF COASTAL COMMUNITIES TO ABRASION IN SAMAS, BANTUL REGENCY, INDONESIA
}

\author{
Audi Karina Choirunnisa, SRi Rum Giyarsih \\ Department of Environmental Geography, Universitas Gadjah Mada, Yogyakarta, Indonesia
}

Manuscript received: November 29, 2017

Revised version: August 3, 2018

\begin{abstract}
CHOIRUNNISA A.K., GIYARSIH S.R., 2018. The socioeconomic vulnerability of coastal communities to abrasion in Samas, Bantul Regency, Indonesia. Quaestiones Geographicae 37(3), Bogucki Wydawnictwo Naukowe, Poznań, pp. 115-126. 4 figs, 5 tables.

ABSTRACT: This research was conducted in Srigading and Gadingsari Villages, Samas District, Bantul Regency, the Special Region of Yogyakarta. Both of these villages were selected as the study area because of their high vulnerability to coastal erosion. This research aimed to analyse the physical, social, and economic vulnerability and the capacity of communities in both villages to deal with erosion in Samas Coast using primary and secondary database. According to the results of the physical and socioeconomic scenarios, Srigading has a high vulnerability level, whereas Gadingsari has a low vulnerability level. Meanwhile, the equal scenario results in the same spatial distribution of vulnerability as the aforementioned scenarios. This research also finds that the capacity, which was based on knowledge of coastal erosion and its risk reduction measures, is categorized as medium. This capacity level is shaped by the constantly improved preparedness as communities experience coastal erosions directly.
\end{abstract}

KEY wORDS: coastal erosion, physical vulnerabilities, social vulnerabilities, economic vulnerabilities, SMCE method, Samas Coast

Corresponding author: Giyarsih S.R., srirum@ugm.ac.id

\section{Introduction}

Climate change is a global issue that significantly affects archipelagic countries (Hereher 2016, Schmutter et al. 2017, Senapati, Gupta 2017,). This issue also applies to the biggest archipelago in the world, Indonesia. It consists of 13,466 islands with $81,000 \mathrm{~km}$ long shoreline and seas as wide as 3.1 million $\mathrm{km}^{2}$ or $62 \%$ of its territorial area (UNCLOS 1982). According to the Climate Conference in Warsaw, the coastal regions in Indonesia are inhabited by 42 million people and predicted to experience the negative impact of climate change (Duckers et al. 2015, Neale, Weir 2015, Taylor, Peace 2015, Ullah et al. 2015). The impact is felt particularly in Java Island because $65 \%$ of its population lives in coastal regions and grows by $2.2 \%$ per year, which is higher than the national average growth rate (Miladan 2009). Setiyono (1996) states that erosion is the process of coastal material removal by the destructive force of sea waves and currents. Similar phenomena are also explained by Mahapatra (2015), Fitton et al. (2016), Merlotto et al. (2016), Ghosh (2017), Yankson et al. (2017), Bevacqua et al. (2018), Chang et al. (2018), and Onat et al. (2018). Breaking waves are also able to transport or move loose materials on the shoreline into the sea, generating an abrasion process (Sutikno 1999, Marfai et al. 2008, Wesli et al. 2013, Widianto, Damen 2014). From strategic point of view, the impact of abrasion is a decline in land surface; while from environmental point of view, it is the loss of habitats in an ecosystem 
(Ongkosongo 2011). Marfai (2011) explains that coastal erosion has serious negative impact, such as damaged public facilities and settlements as well as deforestation, which are argued to be the triggers for the widespread negative impact of coastal erosion.

Coastal erosion is a significant implication of sea level rise on sandy or muddy beach that induces shoreline change as a form of equilibrium beach profile (Marfai, King 2008, Numberi 2009). According to the Regional Disaster Management Agency of Bantul Regency, the coastal regions in the southern area experience large waves and coastal erosions every year. Coastal erosion wears away most of the land along the beach and causes harm to the society (BNBD Kabupaten Bantul, 2016). Among the other coasts in South Bantul, Samas Coast suffers from the severest erosion. This condition is due to sands blocking the mouth of Opak River, which cause a lagoon to form and prevent the river water from flowing into the sea. The Office of Marine Affairs and Fisheries of Bantul Regency states that the lagoon has potentials for marine tourism and that it can improve regional economy and local welfare (DKP Kabupaten Bantul 2016). Therefore, physical infrastructures and facilities become necessary to support it as a tourist attraction (Sidik 2013). However, intensive erosion will remain a threat to the sustainability of its development if the problems induced by coastal erosion are not solved immediately.

The extent of coastal erosion impact is strongly influenced by the capacity or the vulnerability of at-risk elements. Van Westen and Soeters (2006) defines at-risk elements as all objects, humans, animals, and activities or processes, including buildings, public facilities, population, economic activities, and environments, that are affected by a disaster event in an area either directly or indirectly. Meanwhile, capacity is depicted as ability, i.e. the combination of all of the strengths of a society, a social community, or an organization that can reduce the impact of risks or hazards. It is formed through various economic, social, or institutional ways, individual or communal skills, as well as organizations or leaderships that result in the reduction of risk or hazard level. In terms of disaster risk reduction, capacity is influenced by, for example, the functions of available resources in an area (UNISDR 2004).
Vulnerability is the exposure level of at-risk elements (humans and things) to threats (Maarif et al. 2014, Islam et al. 2016, Nur, Shrestha 2017, Raufirad et al. 2017, Yadav, Barve 2017, Jurjonas, Seekamp 2018). It represents the condition of a society or a community that shapes their inability to deal with and minimize the impact of hazards, which will lead to damages and disruptions if disaster attacks (Sutikno 2002, UNDP 2004, Bakornas PB 2007, Sakijege 2013, Rijanta et al. 2014, Zorn, Shamseldin 2015, Figerio, Amicis 2016, Fatemi et al. 2017, De Silva et al. 2018). In disaster management context, this condition is determined by physical, social, economic, and environmental factors or processes (UNISDR 2009) that control the ability to prevent, mitigate, prepare, and respond to the impact of hazards.

The spatial presentation of disaster information is essential for risk reduction particularly in providing data that can be utilized directly by the society to familiarize themselves with the condition of their environment (Setyaningrum, Giyarsih 2012, Rachmawati, Budiarti 2016). Therefore, the extent of coastal erosion impact can be minimized by initially providing disaster information. Based on the authors' knowledge, no research has specifically documented the socioeconomic vulnerability of the population to coastal erosion and the community capacity in Samas Coast to deal with coastal erosion. Referring to this background, this research becomes necessary. This research applied this mitigation measure by aiming to (1) analyse the physical, social, and economic vulnerability level in Samas Coast and (2) analyse the capacity of the local communities to deal with coastal erosion in the study area.

\section{Research method}

This research was conducted in Srigading and Gadingsari Villages, Samas District, Bantul Regency with survey method. In order to achieve the first objective, i.e. to analyse the physical, social, and economic vulnerability, this research applied the Spatial Multi Criteria Evaluation (SMCE) method. In this case, the SMCE employed a weighting method using pairwise comparison. Meanwhile, in order to achieve the second objective, i.e., to analyse the capacity level 
of the local population, it used scoring technique and statistical data analysis on the result of the structured interview. SMCE is a vulnerability assessment method that uses both spatial and statistical data as an input to produce a map with composite index. In this research, the spatial variable (i.e. physical parameter) was combined with the quantitative data (i.e. socioeconomic parameter) producing a composite map with spatial information and statistical attributes. The output of this method can assist in planning and decision making for development policy more specifically compared to statistic data presentation like graph, table, picture, chart, and calculation (Rahmat 2015).

The analysis unit was village, especially the villages located in highly vulnerable areas to coastal erosion. The variables of vulnerability in this research are presented in Table 1. The SMCE method for vulnerability assessment consisted of four steps, namely structuring the problem into criteria tree, standardization, weighting, and selecting scenario. The output of this method is a vulnerability map with spatial information and statistical attributes.

In order to assess the capacity level of the communities, the households were selected using multistage random sampling technique. Based on the Harry King's Nomogram (Fig. 1), a

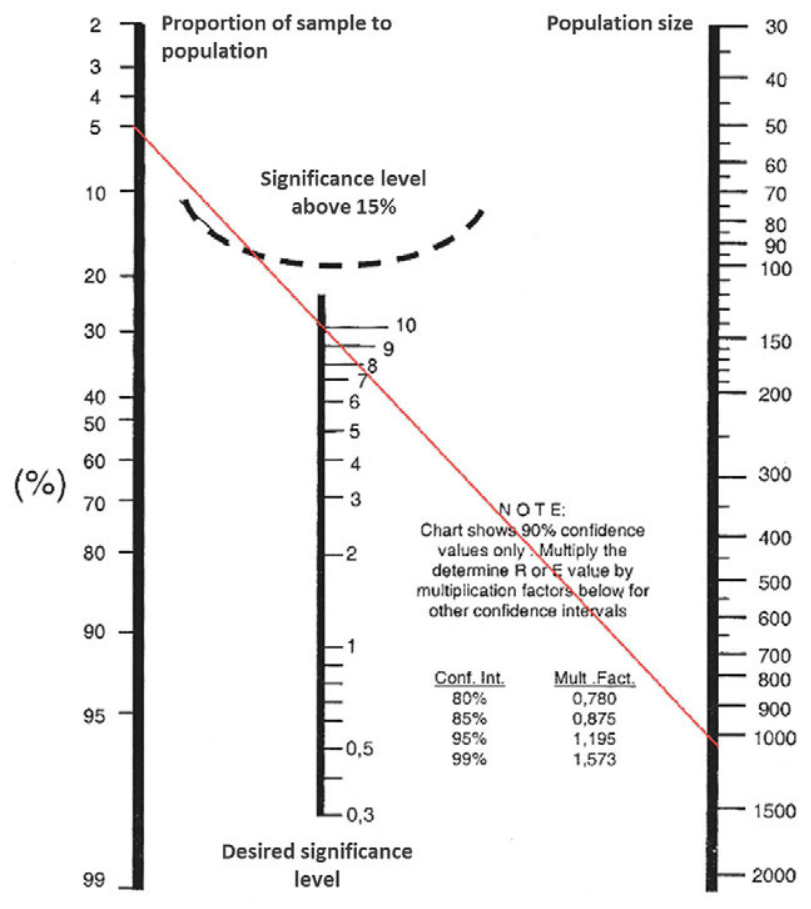

Fig. 1. Harry King's nomogram acc. to Setyaningrum, Giyarsih (2012).

$90 \%$ confidence level requires a sample size of 5\% of the total population. Gadingsari and Srigading Village have 395 and 713 households, respectively. Therefore, a 90\% confidence level over a total population of 1,108 households requires the following sample size:

Table 1. Research variables.

\begin{tabular}{|c|c|c|c|}
\hline Objectives & Factors & Variables & Descriptions \\
\hline \multirow{12}{*}{ Vulnerability } & \multirow[t]{3}{*}{ Physical } & Number of houses & The higher, the more vulnerable \\
\hline & & Distance to shoreline & The closer to shoreline, the more vulnerable \\
\hline & & House types & $\begin{array}{l}\text { Non-permanent house is more vulnerable than the perma- } \\
\text { nent one }\end{array}$ \\
\hline & \multirow[t]{5}{*}{ Social } & Population size & The higher, the more vulnerable \\
\hline & & Sex & Women are more vulnerable than men \\
\hline & & Age & Elderly and children cause more vulnerability \\
\hline & & Education & The higher, the less vulnerable \\
\hline & & Number of disabled people & The higher, the more vulnerable \\
\hline & \multirow[t]{4}{*}{ Economic } & Job & People with professional jobs are less vulnerable \\
\hline & & Unemployment & The higher, the more vulnerable \\
\hline & & Number of poor household & The higher, the more vulnerable \\
\hline & & Economic facilities & The higher, the more vulnerable \\
\hline \multirow{5}{*}{$\begin{array}{l}\text { Community } \\
\text { capacity }\end{array}$} & \multirow{5}{*}{$\begin{array}{l}\text { Knowledge } \\
\text { of abrasion }\end{array}$} & Abrasion & The more the knowledge, the less vulnerable \\
\hline & & The cause of abrasion & The more the knowledge, the less vulnerable \\
\hline & & The impact of abrasion & The more the knowledge, the less vulnerable \\
\hline & & $\begin{array}{l}\text { The countermeasures of } \\
\text { abrasion }\end{array}$ & The more the knowledge, the less vulnerable \\
\hline & & $\begin{array}{l}\text { Abrasion risk reduction } \\
\text { measures }\end{array}$ & The more the knowledge, the less vulnerable \\
\hline
\end{tabular}


Table 2. The classification of capacity levels.

\begin{tabular}{|l|c|l|}
\hline Classes & Total scores & \multicolumn{1}{c|}{ Descriptions } \\
\hline Low & $6-13$ & $\begin{array}{l}\text { Lack of capacity to implement } \\
\text { disaster risk reduction }\end{array}$ \\
\hline Medium & $14-22$ & $\begin{array}{l}\text { Adequate capacity to imple- } \\
\text { ment disaster risk reduction }\end{array}$ \\
\hline High & $23-30$ & $\begin{array}{l}\text { High capacity to implement } \\
\text { disaster risk reduction }\end{array}$ \\
\hline
\end{tabular}

Gadingsari Village:

$395 / 1,108 \times 56=20$ households,

Srigading Village:

$713 / 1,108 \times 56=36$ households,

Total $=56$ households.

Meanwhile, the capacity level was obtained using Likert (1932) scaling on the information provided by the respondents. It was divided into three classes, namely low, medium, and high (Table 2).

\section{Results and discussion}

\section{Susceptibility to coastal erosion}

The susceptibility of coastal areas to erosion is determined by wave height, the composition of beach substrate, beach form, shoreline development, mangrove habitat, and residential site. These factors, also the variables of susceptibility in this research, consisted of several criteria whose scores represented their levels of influence on coastal erosion event. The higher the score of a variable, the stronger its influence to determining the susceptibility level. The susceptibility map provides information on different levels of susceptibility, namely low, medium, and high (see Fig. 2). More than half of the coastal riparian area in Samas, i.e. $74.83 \%$, is highly susceptible especially the one with a residential area of more than 6.09 ha (see Table 3). On the contrary, coasts with

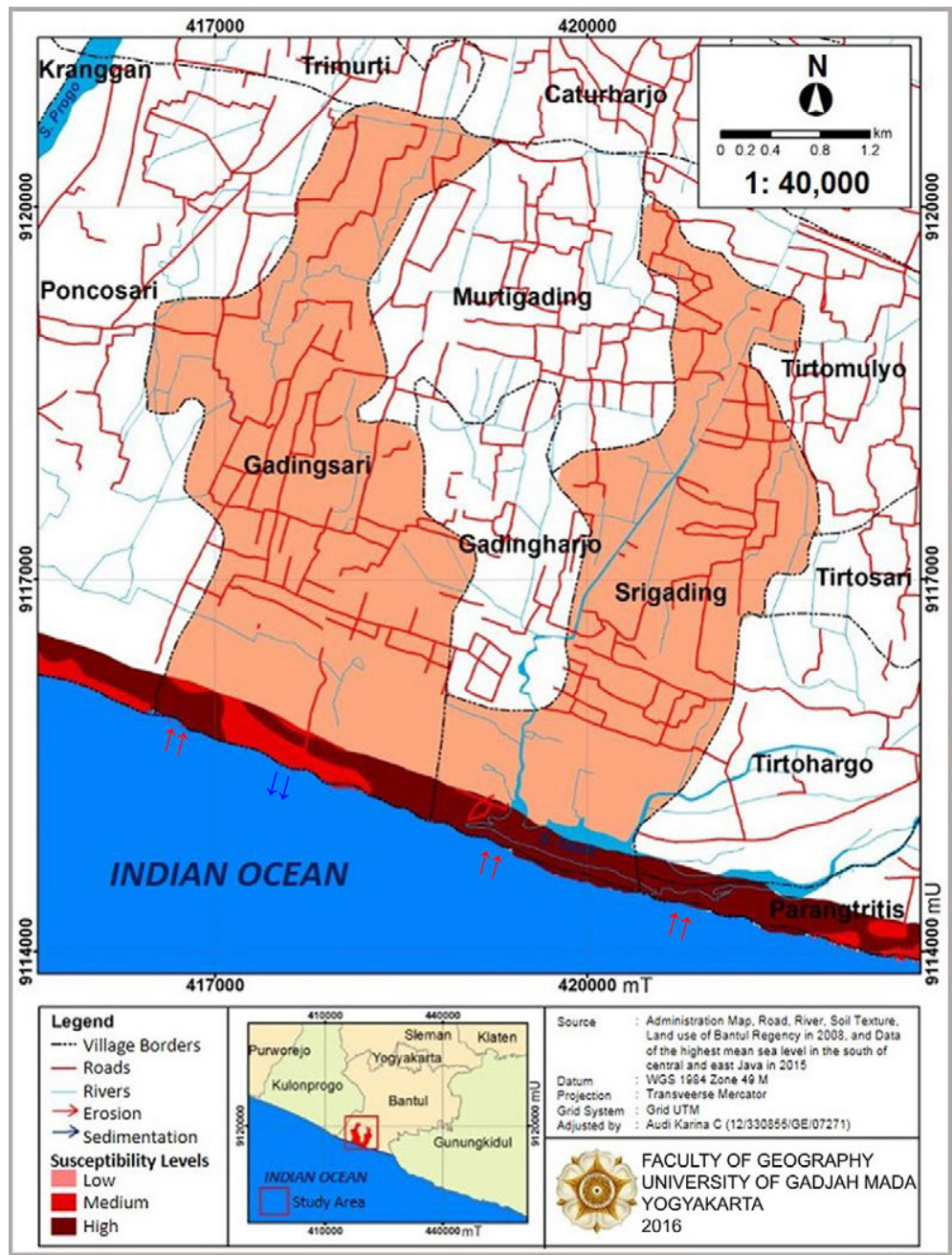

Fig. 2. The erosion susceptibility map of Samas Coast by Choirunnisa (2016). 
Table 3. The extent of susceptible area to coastal erosion based on land use.

\begin{tabular}{|l|c|c|}
\hline \multicolumn{1}{|c|}{ Land use } & Vulnerability classes & Area (ha) \\
\hline Beach sands & Medium & 12.08 \\
\hline Beach sands & Medium & 13.39 \\
\hline Beach sands & Medium & 16.40 \\
\hline Beach sands & High & 23.07 \\
\hline Beach sands & High & 6.07 \\
\hline Beach sands & High & 43.14 \\
\hline Settlement & High & 6.09 \\
\hline Grass & High & 2.14 \\
\hline Irrigated rice field & Medium & 4.46 \\
\hline Irrigated rice field & High & 27.06 \\
\hline Irrigated rice field & High & 6.43 \\
\hline Dry land & Medium & 2.25 \\
\hline Dry land & Medium & 1.91 \\
\hline Dry land & High & 0.30 \\
\hline Dry land & High & 3.64 \\
\hline Water body & High & 22.71 \\
\hline Water body & High & 9.51 \\
\hline
\end{tabular}

mangrove habitat (natural wave barrier) or other factors that reduce the susceptibility level can minimize the extent of land affected by sea wave and coastal erosion.

\section{Physical, social, and economic vulnerability assessment}

The SMCE method for vulnerability assessment consisted of four steps, namely structuring the problem into criteria tree, standardization, weighting, and selecting scenario, that produced vulnerability maps from a combination of variables with different standards and types. These maps show different determinants of vulnerability in each village in the study area. Several scenarios were made for identifying the most influencing factors to vulnerability. The equal scenario applies the same weight to every factor, i.e. 0.33 .

Meanwhile, in physical scenario, the weights are 0.6 and 0.2 for the factors of physical vulnerability and socioeconomic vulnerability, respectively. Furthermore, the weights in socioeconomic scenario are 0.143 and 0.429 respectively for the factors of physical and socioeconomic vulnerability. The vulnerability index consists of five classes and varies between $0-1$. The closer the index to 1 , the more the vulnerability.

\section{Physical vulnerability}

According to the physical vulnerability classes, Srigading is more vulnerable to coastal erosion than Gadingsari because, spatially, the former village has the closest houses to shoreline and lagoon. This finding is in line with the results of the weighting process in SMCE in which the variable with the highest weight is the distance between house and shoreline. Therefore, the absence of houses located close to the shoreline in Gadingsari makes this village have a lower vulnerability despite its higher number of permanent houses than Srigading. In other words, if coastal erosion occurs in Gadingsari, the houses in this village will not be affected directly by sea wave. A high physical vulnerability indicates the need to increase people's awareness of residential sites whose locations have to be in accordance with the spatial plan.

\section{Social vulnerability}

The variable with the most weight in determining vulnerability is population size. In terms of social vulnerability, Gadingsari is more vulnerable than Srigading, indicating the presence of more at-risk social elements in Gadingsari. A high social vulnerability is caused by a large number of demographically disadvantaged populations, such as elderly, toddlers, children, and disabled people. A large share of this population group likely increases the exposure level of a village to the impact of disasters.

\section{Economic vulnerability}

The number of poor household has the highest weight in determining the economic vulnerability. Similar to the social vulnerability, Gadingsari is more economically vulnerable than Srigading. Gadingsari has a low economic condition that is indicated by a large number of poor households and unemployed people. At the same time, people whose jobs are affected by disasters contribute to the low economic condition in this village. These jobs are mostly in agricultural sector or with high dependence on natural condition in which weather and soil become the determinants of the economic condition. Compared to those who work in sectors that are unaffected by disasters, people with natural resource-dependent jobs strongly influence the vulnerability level of a village. In addition, a low economic condition results in poverty (Giyarsih 2014). Poor households tend to have poor access to many sectors, including education, health, and other socioeconomic 

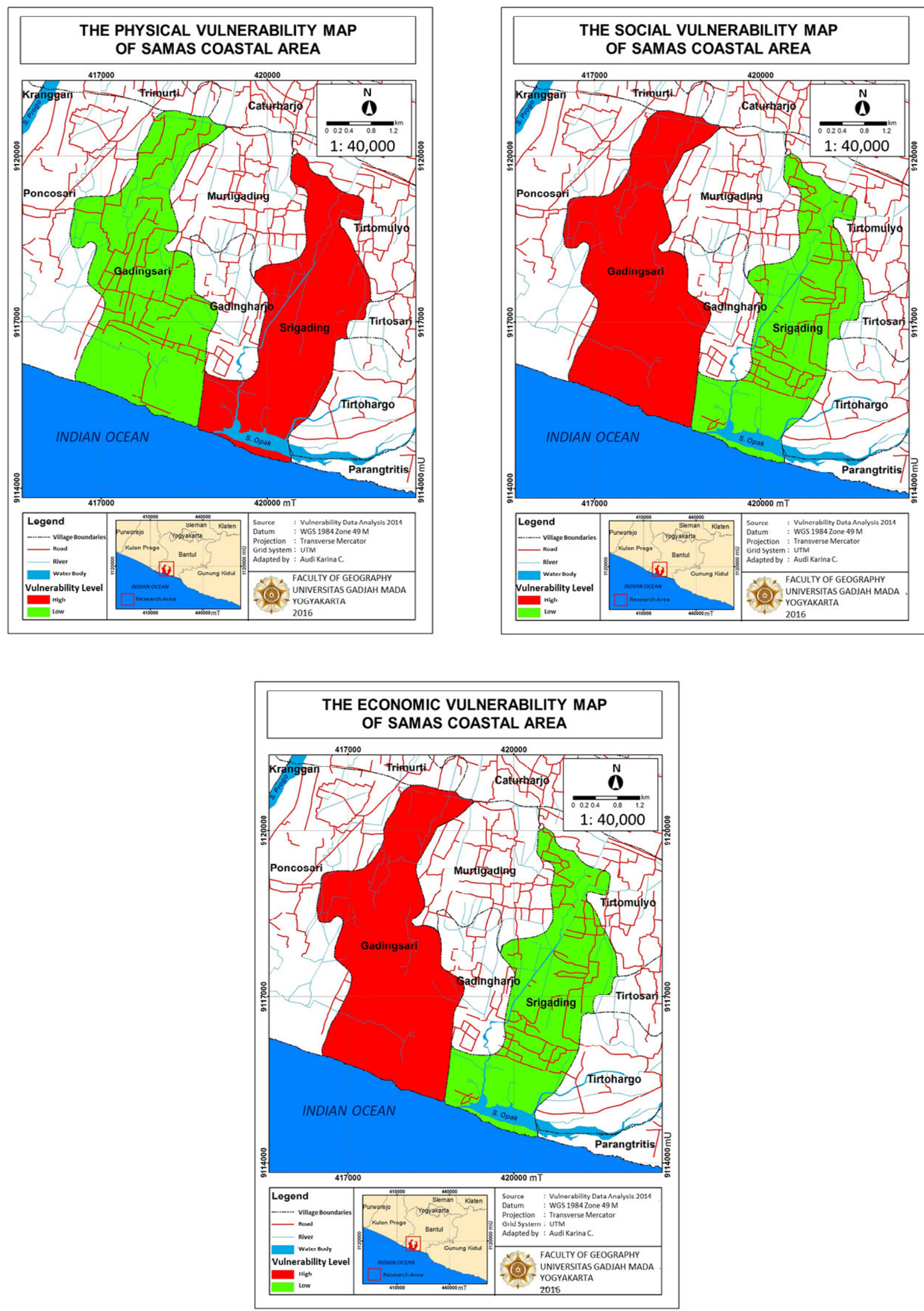

Fig. 3. Maps of physical, social, and economic vulnerability by Choirunnisa (2016). 

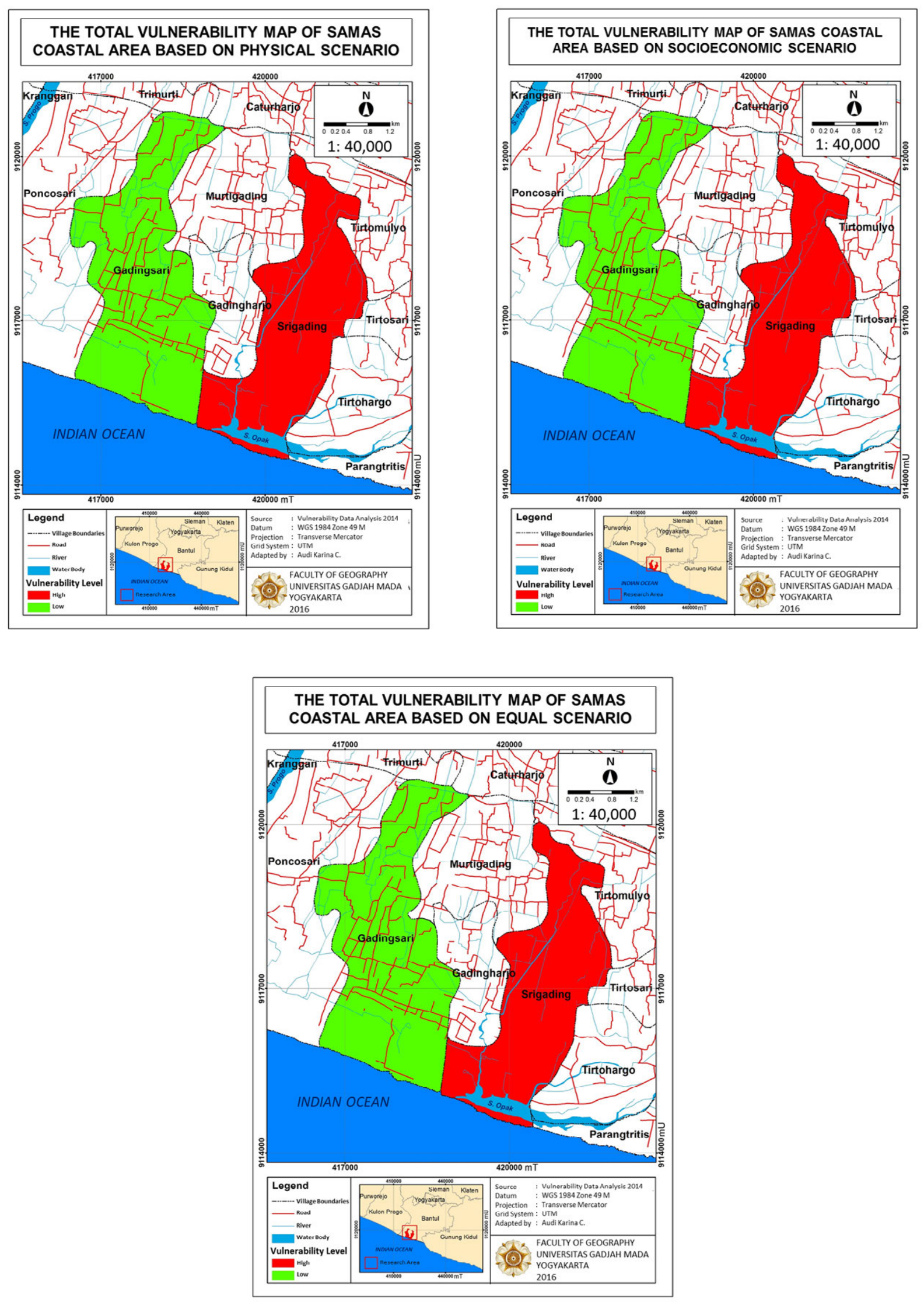

Fig. 4. Maps of total vulnerability with physical, socioeconomic, and equal scenarios by Choirunnisa (2016). 
services. This condition economically exposes many people in Gedangsari to disasters. After the wake of disasters, villages with high economic vulnerability require a long recovery time.

\section{Total vulnerability}

Total vulnerability is the analysis result of three vulnerability values, namely physical vulnerability, social vulnerability, and economic vulnerability. These three vulnerabilities are weighted based on the scenarios proposed in this research, i.e. physical scenario, socioeconomic scenario, and equal scenario. Each scenario represents the level of influence of each factor in shaping vulnerability.

\section{Physical scenario}

Based on the results of the physical scenario, Srigading is more vulnerable than Gadingsari because it has several buildings that are located closer to lagoon and shoreline than the buildings in Gadingsari. Therefore, the distance factor is very influential in increasing the vulnerability level. This finding is in line with Rahmat (2015) and Rizal (2015), which state that the distance between hamlets and Putih River contributes to the high physical vulnerability to lahar from Merapi Volcano. However, this finding is different from Armaya (2015) and Sauri (2016), which state that villages with a large number of buildings are more vulnerable than the ones with few buildings. Even though the total number of settlement in Gadingsari is higher than in Srigading, the residential sites are located far from the shoreline and outside of the coastal riparian area. On the contrary, Srigading has fewer residential sites that are located very close to the lagoon and shoreline, i.e. approximately $45 \mathrm{~m}$. Therefore, Srigading has a higher proneness to the impact of coastal erosion.

\section{Socioeconomic scenario}

Based on the socioeconomic scenario, Srigading is more vulnerable than Gadingsari. The population size of Gadingsari is slightly larger than Srigading, while the economic conditions of both villages are similarly low. Therefore, the socioeconomic vulnerability levels of the two villages are equally high. However, the results of slicing into three classes show that Srigading is more vulnerable due to its physical factors. Despite the low weight of physical parameter in the socioeconomic scenario, it still plays a role in creating a higher vulnerability in Srigading. The influential physical parameter is the distance between settlement blocks and shoreline. In this case, the distance is only $45 \mathrm{~m}$. This finding is in line with Rahmat (2015), which states that a high vulnerability in socioeconomic scenario is not only influenced by population size and the number of poor household but also the distance between hamlets and Putih River, i.e. a river through which the lahar of Merapi Volcano traverses.

\section{Equal scenario}

Equal scenario applies the same weight to physical, social, and economic factors. In other words, each of these factors has the same influence on vulnerability level. Based on the total vulnerability map obtained from the equal scenario, Srigading is more vulnerable than Gadingsari. This finding is in line with Sauri (2016), which states that villages with high vulnerability are the ones located close to or within the source of disaster. Spatially, Srigading is closer to the lagoon and some of its settlement blocks are closer to the shoreline. In addition, due to its large number of population, poor households, and houses, it is more vulnerable than Gadingsari.

The results of these three vulnerability scenarios can assist in the making of disaster mitigation policy as a measure of risk reduction to coastal erosion. The maps of physical, social, and economic vulnerability are presented in Figure 3, while the maps of total vulnerability from physical, socioeconomic, and equal scenarios are presented in Figure 4.

\section{Community capacity}

The capacity of the communities in both villages was assessed using cross table analysis on the relationship of two variables: 1) the distance between houses and shoreline and 2) knowledge of coastal erosion. These variables were selected in consideration of their inversely proportional relationship. The closer the distance between the houses and shoreline, the wider people's knowledge of coastal erosion is. According to the contingency coefficients presented in Table 4, the significance value is 0.180 . Since it is $<0.5$, there is a close or mutually influential relationship 
Table 4. Contingency coefficients.

\begin{tabular}{|l|l|c|c|}
\hline \multicolumn{2}{|c|}{ Symmetric Measures } & Value & Approx. Sig. \\
\hline \multirow{2}{*}{$\begin{array}{l}\text { Nominal by } \\
\text { Nominal }\end{array}$} & Phi & 0.335 & 0.180 \\
\cline { 2 - 4 } & Cramer's V & 0.237 & 0.180 \\
\cline { 2 - 4 } & $\begin{array}{l}\text { Contingency } \\
\text { coefficient }\end{array}$ & 0.317 & 0.180 \\
\hline \multicolumn{2}{|l|}{ N of valid cases } & 56 & \\
\hline
\end{tabular}

between the distance of houses from shoreline and people's knowledge of coastal erosion.

Based on the interviews with the local communities in Srigading, people living close to the shoreline have more comprehension on the proneness of their settlements to coastal erosion. This comprehension is obtained from experiences and stories passed down from their parents. Nevertheless, they cannot do anything except saving their belongings and leaving their houses when indications of severe coastal erosion appear because, on one side, they perceive coastal erosion as a natural and unavoidable phenomenon. On the other side, they perceive the coast as their livelihood. Meanwhile, the closest distance between the houses in Gadingsari and the shoreline is $>300 \mathrm{~m}$. Even though these houses are outside of the coastal riparian area, the people living there understand the proneness of their settlements to coastal erosion, which are similar to those living in Srigading.

Most of the people in Srigading and Gadingsari who live either close to or far from the shoreline chose the options "agree" and "highly agree" regarding the oral or written information and public dissemination on the threats of coastal erosion that they had received from the government and other institutions. Information on the threats of coastal erosion is generally obtained from experiences, stories passed down by the parents, and chains of information between the villagers. In addition, information provided by the government of each village influences the level of people's awareness in anticipating possible threats from coastal erosion. It is usually disseminated prior to raised alert status, at evacuation drills, and during village meetings.

Disaster management is necessary to minimize the risks posed by coastal erosion. Based on the results of the interviews, the people in Srigading gave various responses to the questions regarding the existence of disaster management. Meanwhile, 55\% of the people in Gadingsari stated that Samas Coast lacked mitigation measures against abrasion as well as coastal erosion management from the government, other institutions, and local communities. On the contrary, according to the Head of Regional Disaster Management Agency (BPBD), the government has established various preventive measures like planting beach she-oaks (Casuarina equisetifolia) and providing sand-filled plastic bags. However, these measures are considered less successful in reducing the risks of coastal erosion because the characteristics of sea wave and beach morphology in the study area make the impact of coastal erosion exceed the capacity of such measures. Furthermore, several members of the local communities have been implementing preventive measures based on their first-hand experiences on coastal erosion.

Most of the people in Srigading and Gadingsari who live either close to or far from the shoreline understand the general idea of how to prevent coastal erosion. Such comprehension is shown by their agreement to the implementation of local wisdom into preventive measures, e.g. suitable land utilization in Samas Coast, indicating that the local communities have invented their own ways to deal with the threats posed by coastal erosion.

The capacity level of the people in Srigading and Gadingsari is categorized as low. In Srigading, $25 \%$ and $63.89 \%$ of its people have respectively high and medium capacity. Meanwhile, in Gadingsari, 35\% and $65 \%$ of its people have respectively high and medium capacity (see Table

Table 5. Number of respondents in Srigading and Gadingsari based on capacity level and distance between houses and shoreline.

\begin{tabular}{|c|c|c|c|c|c|c|c|c|c|c|}
\hline \multirow{3}{*}{ Capacity levels } & \multicolumn{10}{|c|}{ Distance between Houses and Shoreline } \\
\hline & \multicolumn{5}{|c|}{ Srigading } & \multicolumn{5}{|c|}{ Gadingsari } \\
\hline & Near & Moderate & Far & Total & $\%$ & Near & Moderate & Far & Total & $\%$ \\
\hline Low & 0 & 1 & 3 & 4 & 11.11 & 0 & 0 & 0 & 0 & 0 \\
\hline Medium & 4 & 10 & 9 & 23 & 63.89 & 0 & 0 & 13 & 13 & 65 \\
\hline High & 6 & 3 & 0 & 9 & 25.00 & 0 & 0 & 7 & 7 & 35 \\
\hline
\end{tabular}


5). Due to first-hand experiences on coastal erosion, most of the people in these two villages try to reduce the possible loss caused by recurring coastal erosion. The government officials of Srigading and Gadingsari have appealed for the development of settlements far from the shoreline. Nowadays, the houses along the shoreline are abandoned in order to prevent fatalities whenever coastal erosion attacks.

\section{The Relationship between vulnerability and community capacity}

In general, based on the three scenarios of total vulnerability, Srigading has a higher vulnerability level than Gadingsari. In addition, the results of the interviews show that the capacities of the people in Srigading and Gadingsari are classified as medium to high. These two statements postulate a directly proportional relationship between the vulnerability and the community capacity in the study area. The higher the vulnerability level, the higher the community capacity to deal with coastal erosion.

Despite the long distance between the houses and the shoreline (i.e. $1 \mathrm{~km}$ ) as well as the lack of first-hand experience on coastal erosion, the people in Gadingsari have adequate knowledge of coastal erosion and its countermeasures. On the other hand, the people in Srigading, particularly those who live close to or less than 300 $\mathrm{m}$ from the shoreline, have a wide knowledge of coastal erosion, which increases their ability to deal with its negative effects. In general, because they have experienced coastal erosion directly, they understand its characteristics and become adept at dealing with it. When high vulnerability meets low capacity, high disaster risk emerges. Thereby, community capacity enhancement has to be implemented by various parties in order to avoid significant losses when disaster strikes.

\section{Conclusion}

Based on the results of the physical, social, and economic vulnerability assessments using the SMCE method, this research decided to compare three scenarios of total vulnerability, namely physical scenario, socioeconomic scenario, and equal scenario. The physical and socioeconomic scenarios show that Srigading has a high vulnerability level, whereas Gadingsari has a low vulnerability level. In addition, the spatial distribution of the total vulnerability produced from equal scenario is the same as that of physical and socioeconomic scenarios. As a conclusion, both physical and socioeconomic scenarios produce relevant outputs because they give the same result and distribution as the equal scenario.

Furthermore, in terms of physical parameter, Srigading is more vulnerable than Gadingsari because its settlement is located close to the shoreline that receives direct impact from coastal erosion. Meanwhile, based on the social and economic parameters, Gadingsari is more vulnerable than Srigading because it has higher population number as well as a higher share of demographically disadvantaged people (i.e. women, toddlers, children, elderly, and disabled people). Because many social variables are vulnerable or exposed to coastal erosion risk, Gadingsari has a high social vulnerability. Moreover, a large number of poor households, unemployed people, as well as people whose jobs are affected by coastal erosion lead to the more presence of at-risk economic elements in this village.

The paucity of economic facilities shows that both Srigading and Gadingsari have low economic condition, which influences the community capacity in terms of disaster mitigation and post-disaster recovery. Based on the knowledge of coastal erosion and its risk reductions, the capacities of the people in both villages are categorized as medium. This level of capacity is influenced by first-hand experiences on coastal erosion that increase the awareness of the local communities, particularly those who live close to shoreline.

\section{Acknowledgments}

We would like to express our gratitude to the Faculty of Geography, Universitas Gadjah Mada for the financial support through the scheme of Lecturer Research Grant, Faculty of Geography, Universitas Gadjah Mada in 2016. We would also like to thank Dr. Sukamdi, M.Sc for his invaluable input to this article. We would like to acknowledge Ajeng Larasati, M.Sc. for her linguistic assistance. 


\section{References}

Armaya D.A.B., 2015. Penaksiran Tingkat Kerentanan Sosial Terhadap Bahaya Banjir Lahar Pasca Erupsi Gunungapi Merapi. MS. Faculty of Geography, Universitas Gadjah Mada.

BAKORNAS PB., 2007. Panduan Pengenalan Karakteristik Bencana dan Upaya Mitigasinya di Indonesia. Jakarta, BAKORNAS PB.

Bevacqua A., Yu D., Zhang Y., 2018. Coastal Vulnerability: Evolving Concepts in Understanding Vulnerable People and Place. Environmental Science and Policy 82: 19-29.

BNPB Kabupaten Bantul., 2016. Annual Report. Regional Disaster Management Agency of Bantul Regency. Yogyakarta, BNPB.

Chang S.E.,Yip J.Z.K., Conger T., Oulahen G., Marteleira M., 2018. Community Vulnerability to Coastal Hazards: Developing A Typology for Disaster Risk Reduction. Applied Geography 91: 81-88.

Choirunnisa A.K., 2016. Kajian Kerentanan Fisik, Sosial, dan Ekonomi Pesisir Samas Kabupaten Bantul Terhadap Erosi Pantai. MS. Fakultas Geografi UGM.

De Silva M.M.G.T., Kawasaki A., 2018. Socioeconomic Vulnerability to Disaster Risk : A Case Study of Flood and Drought Impact in A Rural Sri Lankan Community. Ecological Economics 152: 131-140.

DKP Kabupaten Bantul, 2016. Annual Report. Office of Marine Affairs and Fisheries of Bantul Regency. Yogyakarta, DKP Kab. Bantul.

Duckers M., Frerks G., Birkmann J., 2015. Exploring the Plexus of Context and Consequences: An Empirical Test of A Theory of Disaster Vulnerability. International Journal of Disaster Risk Reduction 13: 85-95.

Fatemi F., Ardalan A., Aguirre B., Mansouri N., Mohammadfam I., 2017. Social Vulnerability Indicaors in Disasters: Findings From A Systematic Review. International Journal of Risk Reduction 22: 219-227.

Ferrol-Schulte D., Gorris P., Baitoningsih W., Adhuri D.S., Ferse S.C.A. 2015. Coastal livelihood vulnerability to marine resource degradation: A review of the Indonesian national coastal and marine policy framework. Marine Policy 52: 163-171.

Figerio I., Amicis M.D., 2016. Mapping Social Vulnerability To Natural Hazards in Italy: A Suitable Tool for Risk Mitigation Strategies. Environmental Science \& Policy 63: 187-196.

Fitton J., Hansom J.D., Rennie A.F., 2016. A National Coastal Erosion Susceptibility Model for Scotland. Ocean and Coastal Management 132: 80-89.

Ghosh A., 2017. Quantitative Approach on Erosion Hazard, Vulnerability and Risk Assessment: Case Study of Murigangga-Saptamukhi Interfluve, Sundarban, India. Natural Hazards 87: 1709-1729.

Giyarsih S.R., 2014. Pengentasan Kemiskinan Yang Komprehensif di Bagian Wilayah Terluar Indonesia, Studi Kasus Kabupaten Nunukan Provinsi Kalimantan Utara. Jurnal Manusia dan Lingkungan 21(2): 230-246.

Hererher M.E., 2016. Vulnerability Assessment of the Saudi Arabian Red Sea Coast to Climate Change. Environmental Earth Sciences 75: 30.

Islam M.A., Mitra D., Dewan A., Akhter S.H., 2016. Coastal Multi-Hazard Vulnerability Assessment Along the Ganges Deltaic Coast of Bangladesh-A Geospatial Approach. Ocean \& Coastal Management 27: 1-15.
Jurjonas M., Seekamp E., 2018. Rural Coastal Community Resilience: Assessing A Framework in Easter North Carolina. Ocean and Coastal Management 162: 137-150.

Likert R., 1932. A Technique for The Measurement of Attitudes. New York. New York University.

Maarif S., Damayanti F., Suryanti E.D., Wicaksono A.P., 2014. Initiation of Desa Tangguh Bencana Through Stimulus-Response Method. Indonesian Journal of Geography 44(2): 173-182.

Mahapatra M., Ramakrishman R., Rajawat S.S., 2015. Coastal Vulnerability Assessment Using Analytical Hierarchical Process for Sout Gujarat Coast, India. Natural Hazard 76: 139-159.

Marfai M.A., King L., 2008. Potential Vulnerability Implication of Coastal Inundation Due to Sea Level Rise for the Coastal Zone of Semarang City, Indonesia. Environmental Geology 54: 1235-1245.

Marfai M.A., King L., Sartohadi J., Sudrajat Budiani S.R., Yulianto F., 2008. The Impact of Tidal Flooding on a Coastal Community in Semarang, Indonesia. Environmentalist 28: 237-248.

Marfai M.A., 2011. The Hazard of Coastal Erosion in Central Java Indonesia: An Overview. Geografia Online 3: 1-9.

Merlotto A.,Bertoal G.R., Piccolo M.C., 2016. Hazard, Vulnerability and Coastal Erosion Risk Assessment in Necochea Municipality, Buenos Aires Province, Argentina. Journal of Coastal Conservation 20: 351-362.

Miladan N., 2009. Kajian Kerentanan Wilayah Pesisir Kota Semarang Terhadap Perubahan Iklim. MS. Magister Teknik Pembangunan Wilayah dan Kota Universitas Diponegoro.

Neale T., Weir J.K., 2015. Navigating Scientific Uncertainty in Wildfire and Flood Risk Mitigation: A Qualitative Review. International Journal of Disaster Risk Reduction 13: 255-267.

Numberi F., 2009. Perubahan Iklim: Implikasinya terhadap Kehidupan Laut, Pesisir dan Pulau-Pulau Kecil. Jakarta, Fortuna Prima Makmur.

Nur I., Shrestha K.K., 2017. An Integrative Perspective on Community Vulnerability to Flooding in Cities of Developing Countries. Procesia Engineering 198: 958-967.

Onat Y.,Francis O.P., Kim K., 2018. Vulnerability Assessment and Adaption to Sea Level Rise in High-Wave Environments: A Case Study on O'ahu, Hawai'i. Ocean and Coastal Management 157: 147-159.

Ongkosongo O.S.R., 2011. Strategi Menghadapi Risiko Bencana Di Wilayah Pesisir Akibat Pemanasan Global dan Perubahan Iklim Global. Jakarta, Pusat Penelitian Oseanografi, Lembaga Ilmu Pengetahuan Indonesia.

Rachmawati R., Budiarti C.V., 2016. Use of Space the Need For Planning in the Disaster-Prone Area of Code River, Yogyakarta, Indonesia. Indonesian Journal of Geography 48(2): 178-190.

Rahmat P.N., 2015. Penilaian Kerentanan Fisik, Sosial, dan Ekonomi Dusun-Dusun di Sekitar Kali Putih Terhadap Banjir Lahar Gunungapi Merapi. MS. Faculty of Geography, Universitas Gadjah Mada.

Raufirad V., Heidari Q., Hunter R., Ghorbani J., 2018. Relationship Beween Socioeconomic Vulnerability and Ecological Sustainability: The Case of Aran-V-Bidgol's Ranglands, Iran. Ecological Indicators 85: 613-623.

Rijanta R., Hizbaron D.R., Baiquni M., 2014. Modal Sosial dalam Manajemen Bencana. Yogyakarta, Gadjah Mada University Press. 
Rizal M.A., 2015. Analisis Kerentanan Fisik Bahaya Lahar di Desa Sekitar Kali Putih Kabupaten Magelang. Bachelor Thesis. Faculty of Geography, Universitas Gadjah Mada.

Sakijege T., 2013. Managing Flood Risks: Lessons From Keko Machungwa Informal Settlement in Dares Salaam, Tanzania. Indonesian Journal of Geography 45(1): 1-14.

Sauri S., 2016. Penilaian Tingkat Kerentanan Menggunakan Spatial Multi Criteria Evaluation di Sebagian Daerah Rawan Longsor Kabupaten Bogor. MS. Faculty of Geography, Universitas Gadjah Mada.

Schmutter K., Nash M., Dovey L., 2017. Ocean Acidification: Assesing The Vulnerability of Socioeconomic System in Small Island Developing States. Regional Environmental Change 17(4): 973-987.

Senapati S., Gupta V., 2017. Socio-economic Vulnerability Due To Climate Change: Deriving Indicators for Fishing Comunities in Mumbai. Marine Policy 76: 90-97.

Setiyono H., 1996. Kamus Oseanografi. Yogyakarta, Gadjah Mada University Press.

Setyaningrum P,. Giyarsih S.R., 2012. Identifikasi Tingkat Kerentanan Sosial Ekonomi Penduduk Bantaran Sungai Code Kota Yogyakarta Terhadap Bencana Lahar Merapi. Jurnal Bumi Indonesia 7(1): 56-69.

Sidik H., 2013. Bantul terjunkan tim tangani abrasi Pantai Samas. Antara Jogja. Online: jogja.antaranews.com/berita/315406/ bantul-terjunkan-tim-tangani-abrasi-pantai-samas (accessed in May 20, 2016).

Sutikno, 1999. Karakteristik Bentuk Pantai Materi Perkuliahan Geografi Pesisir Dan Kelautan. Research Report. Yogyakarta, Universitas Gadjah Mada.

Sutikno, 2002. Konsep Dasar Geografi. Jakarta, Direktorat PLP.

Taylor H., Peace R., 2015. Children and Cultural Influence in A Natural Disaster, Flood Response in Surakarta, Indonesia. International Journal of Disaster Risk Reduction 13: 76-84.

Ullah R., Shivakoti G.P., Ali G., 2015. Factors Affecting Farmers'Risk Attitude and Risk Prception: The Case of Khyber Pakhtunkhwa, Pakistan. International Journal of Disaster Risk Reduction 13: 151-157.
UNCLOS, 1982. United Nations Convention on the Law of the Sea. Online: www.un.org/depts/los/convention_agreements/texts/unclos/unclos_e.pdf (accessed in July 12, 2016).

UNDP, 2004. Reducing Disaster Risk. A Challenge for Development. A Global Report, UNDP-Bureau for 109 Crisis Prevention and Recovery (BRCP). New York, United Nations.

UNISDR, 2004. Living with Risk: A Global View of Disaster Reduction Initiatives. Geneva, UN International Strategy for Disaster Reduction.

UNISDR, 2009. Terminology on Disaster Risk Reduction. Jenewa, United Nations.

Van Westen C.J., Soeters R., 2006. Landslide Hazard and Risk Zonation - Why is it still so difficult? Bulletin of Engineering Geology and the Environment 6(2): 167-184.

Wesli, Sirojuzilam, Matondang A.R., Lubis S., 2013. The Effect of Land Use and Community Participation on Flood Control at North Aceh District. Indonesian Journal of Geography 45 (2): 171-186.

Widianto A., Damen M., 2014. Determination on Coastal Belt in the Disaster-Prone Area: A Case Study in the Coastal Area of Bantul Regency, Yogyakarta, Indonesia. Indonesian Journal of Geography 46(2): 125-137.

Yadav D.K., Barve A., 2017. Analysis of Socioeconomic Vulnerability for Cyclone-Affected Communities in Coastal Odisha, India. International Journal of Disaster Risk Reduction 22: 387-396.

Yankson P.W.K., Owusu, A.B., Owusu G., Danquah, J.B., Tetteh J.D., 2017. Assessment of Coastal Communities' Vulnerability to Floods Using Indicator-Based Approach: A Case Study of Greater Accra Metropolitan Area, Ghana. Natural Hazards 89: 661-689.

Zorn C.R., Shamseldin A.Y., 2015. Post-Disaster Infrastructure Restoration: A Comparison of Events for Future Planning. International Journal of Disaster Risk Reduction 13: 158-166. 